\title{
On the romances of marriage, love and solitude: freedom and transgression in Cape York Peninsula in the early to mid twentieth century
}

\author{
Jinki Trevillian
}

\section{Romance and rebellion}

Our romances are lived as much in our imaginations as in reality. Always included in our experiences are the thoughts and feelings that expand beyond the given situation, the things not said or done. These romantic relationships extend boundaries, and are met with repression. Rebellious relationships that break the laws of a society question the values of that society. People desire to protect their intimate stories precisely because of the possibility of public conflict and censure. Theodore Zeldin writes that:

For most of history, love has been considered a threat to the stability of the individual and of society, because stability was usually valued more highly than freedom. ${ }^{1}$

Social attitudes to sex and relationships are internalised. In our cultivation of these values, however, it is our individual take on them that allows for the possibility of change. Social and moral laws define relationships as acceptable or transgressive, and yet there is always room for innovation and exploration when we create a specific intimate and personal space. Each of our intimate relationships has its rich history. In this way it is possible to start revolutions in the bedroom.

\section{Fiction and truth in Cape York Peninsula romances}

This article is based on my oral, archival and literary research into the history of Cape York Peninsula. In working with these oral histories I have become convinced that we need to approach the relation of truths and fictions in our histories as an open-ended and complex issue. To 'read' history as literature helps us to understand the complexities and ambivalences of human history as it is experienced and lived. Jon Simon asks, with reference to the work of Michel Foucault: 
Can we tell, not lies, but different truths about ourselves that will become 'true' ... Parallel to an ethic of permanent resistance is an ethic of perpetual rewriting of the truth of our limits. ${ }^{2}$

There are inescapable fictions in our stories of romance. As in literature, our imagination is invoked to help us make sense of our experiences. As in literature, the use of fiction gives us access to other truths. 'It seems to me that the possibility exists for fiction to function in truth, for a fictional discourse to induce effects of truth, and for bringing it about that true discourse engenders or 'manufactures' something that does not yet exist.' ${ }^{3}$ I would suggest that fiction's access to truth is also a way of bringing to light the emotional and psychic truths so often denied in rational discourse.

Reading history, or more accurately and broadly, reading our past, then becomes an act of 'rewriting'. This opening of the possibilities of our understanding of the past to the imagination is akin to the 'perpetual rewriting' described by Simon as parallel to the ethic of permanent resistance. ${ }^{4}$ Interpretations of the past explore our ethical being and reality, both for individuals and collectively. This attempt at a deeper understanding of human history is what I am engaged in as an oral historian when I tell stories. The particular histories of the people of Cape York Peninsula are connected to shared human experiences of love and relationships, through the universalising themes of philosophy and poetry and the empathic identification of the reader.

\section{Singing songs of love}

Prevailing ideas about love and romance are explored in story and song. Aboriginal laws on sex, marriage and adultery on Cape York Peninsula were traditionally strict but open to challenge. In the south-west, at Pormpuraaw, infatuation of women with men was seen as the result of the men 'singing' the women and was accepted as inevitable. ${ }^{5}$ The virtues of faithfulness were praised but 'sweethearts and extra-marital liaisons were celebrated in myth, ceremonies and increase rites' ${ }^{6}$ Forbidden love received especially devoted attention, while involving tragic consequences.

A traditional romance of illicit love was given a modern (1930s) telling in Ion Idriess' story of the 'runaways' ${ }^{7}$ Idriess and his mates assisted runaway lovers, even though they knew that the warriors chasing them were justified in the pursuit and the execution of the law-breakers, if they were caught. ${ }^{8}$ The dangers and suffering that the young couple endured were, in this as in other literary romances, proof of the strength of their love. Forbidden love changes the world from how we are told it should be, but also confirms the rules.

Aboriginal myths and stories showed 'old-time' love and relationships, with their complex symbols of family and kin, food and environment. New possibilities in relationships needed new romances to describe them. Missionary and teacher 
George Taplin (1889-1979) said of some songs that the Ngarrindjeri of South Australia 'will learn it with great appreciation if it seems to express some feelings which theirs does not'. ${ }^{9}$ Christianity could offer a different marital ideal; Western culture had other romances, in fiction, films and songs.

Stories can disrupt the moral judgement of binaries of good and bad, ${ }^{10}$ opening up other possibilities of how to live and love. History is adept at looking at the social and legal contexts of relationships but the existence of the romances themselves remain disruptive. It is the difference between a musical and a documentary; both forms tell a story about people and the world but in the musical the story is augmented by emotional outbursts of song.

Love disrupts our own storylines. We think we know what we want, how things are going to be, then all of a sudden we feel something we were not expecting. Gwen Molony, from Thursday Island, was an avid reader of romances.

When I was growing up $y^{\prime}$ know I read these love stories; the blond was the bad girl and the nice dark-haired girl she was the heroine.

I said 'When I grow up I'm going to marry a tall dark-headed man with curly hair'. My hero, y'know.

I married a big blond Irishman! ${ }^{11}$

So oral histories are like musicals; narratives are 'disrupted' by songs, poetry and emotion. Sometimes the speaker will literally break into song, or it may be a vignette; a story that sits outside the bigger story but nonetheless adds to it through feeling and colour and detail. The oral histories are also like songs; evocative and haunting. They can be incorporated into other histories but they remain an essentially different way of telling stories of the past.

This paper tells some of these stories at the points where romance runs through them, as marriage or its avoidance, as forbidden love, as songs.

\section{Tradition and the separation of men and women}

Mission dormitories separated boys and girls; the children fished, hunted, ate, bathed, slept and collected wood and water separately. Traditionally, their family and marriage regulated relationships between the sexes. Relationships defined by difference and rigid separation could nonetheless be intimate. Jean George grew up on the Mission at Aurukun but returned to her father's country and the Weipa Mission when she married. Hers was a traditional marriage, which brought Jean into the heart of her extended family.

Jean's husband was injured at Thursday Island during the war and was partially incapacitated. Both her husband's brothers lost their wives, so they shared food with her family. But her brothers-in-law would never speak to Jean. 
And he [my brother-in-law] was a real good hunting man, good hunting man. Go and get fishes for me, and especially big barra, so lovely. And dig wild yams for me, and I have wild yams, he cook it and bring it cooked one for me. He really good, he fed me a lot with different things. ${ }^{12}$

The relationship between food and love is seen here in both a general story of family and community and a personal relationship between two people. Within the boundaries of defined relationships, exchanges of food allowed people to express deep love and affection.

Like our customs, our in-laws they don't talk to us ... he talk to Annie, say 'Take it and share it with mum'. Or sometimes he cook it in the bush and bring cooked one, fish or yam, he wrap it, tie it up with grape-vine, all the yams. And then he shoot birds; geese or brolga, ducks, he bring them, even the inside part, he clean it and cook it and bring it cooked. ${ }^{13}$

It is a gift direct from her brother-in-law to Jean that gives her so much pleasure. 'After his wife die, he give everything to me. And I really enjoyed it!' 'He was really good looking after me ... The other brother too, his wife died. So we were looking after them all, the two brothers and my husband.' 14

Although both Aboriginal 'bora' tradition and missionary rules controlled sexual relations, the missionaries' ideas of appropriate relationships for young women differed greatly from that of the elders. Conflict resulted from the white men's abhorrence of marriages between young women and men who were much older and/or had other wives. The vehement anti-sexual attitude of missionaries meant that relations between male and female were deeply associated with sex and wrong-doing. At Old Mapoon the separation of the sexes was given a powerful symbol in the almond and other trees that were planted there. These were designated as girls' and boys' trees. It is said that the girls' fruit was always sweeter, a knowledge which reveals illicit comparison.

The segregation of the sexes affected adult relationships. Punishments for 'talking to girls', as well as being psychologically damaging, created a charged atmosphere around communication between the sexes. Women were largely absent from working environments with cattle, on boats and in mining camps. Sailors' folklore warned against female presence on boats as 'unlucky' and accidents were often blamed on men having keepsakes from their girlfriends. ${ }^{15}$ The culture of men's work romanticised loneliness and the longings of solitude, in the images of cowboys, sailors and bushmen.

\section{The permission of family and church, or marriage as freedom}

Aboriginal marriage laws were severely disrupted through European invasion and the introduction of the Christian religion, despite continued efforts by the 
old people to force adherence to traditional law. Stories (and punishments) of a 'west coast man' taking an 'east coast woman', have their roots in the Dreaming, 16 but the dislocation of invasion and settlement increased the possibility of new relationships and conflict. Just the presence of the white people offered an alternative. A significant element in Idriess' story of the runaways is that in leaving their land and people, the couple had an alternative place to go because of the Europeans. Taylor tells of an eloping couple that took refuge on a cattle station to escape punishment. ${ }^{17}$ Cautionary stories of 'runaways' may have lost some of their power once new freedoms were glimpsed.

Family opposition was a test to the strength of feeling and commitment of young couples. Objection to prospective sons-in-law was considered a healthy tradition even when it involved threats and violence. Though romantic love was not disregarded, marriages served other purposes. Bound to tradition and an intricate network of kinship, spirituality, land and languages, marriage laws could not be treated lightly.

Gladys Williams' family at Pormpuraaw fought over her husband. The couple weren't 'married' in a State marriage, but living together. They had two boys. ${ }^{18}$ The family did not approve Gladys' choice and her mother had arranged a traditional marriage with another man. The fighting got so bad that Government and Mission authorities sent Gladys and her husband to Palm Island after her husband speared her uncle. ${ }^{19}$ When the couple returned after five years of exile, Gladys' husband and her brother-in-law had to fight and 'talk for him' before they could 'settle down'. The couple were married the Christian way. ${ }^{20}$ Conversion to Christianity made Gladys' marriage possible by giving it an authority that was counter to traditional law, though the social consequences remained formidable.

While some young people rebelled against it, the main objection to traditional marriages came from the Churches. ${ }^{21}$ Missionaries were clearly opposed to the marriage of young women to old men and to polygamy. Ina Hall of Weipa, and from the earlier established site of 20 Mile Mission, describes the enclosure of girls in dormitories by the missionaries to control marriage. ${ }^{22}$

That's when Missionary said 'No, no, no ... God say no more, only one wife' ... [Aboriginal men said] 'No, no, no. You can't take that another woman from me. No, that's my wife!' (they spoke language). [Missionary said] 'Only one woman, you only allowed to have one woman'. They fight over it. ${ }^{23}$

Objection to multiple wives was inherent in European/Christian traditions. The cross-generational issue would seem to be related to more romantic values, culturally expressed in literature. The European sentiment exemplified in stories such as Tristan and Isolde, Romeo and Juliet, or novels such as Charles Dickens' 
Bleak House or George Eliot's Middlemarch, idealised a romantic love based on youth. The patriarch or old man, whether the arranger of marriages or the promised groom, is figured as an obstacle. Young — similar aged — love was a relatively modern European ideal and although incorporated into 'Christian values' can hardly be seen as Biblical. European romantic feeling had been through its own revolution against 'traditional' values, and it is worth noting that these 'mythic' European romances were often tragic, involving social and civil conflict.

Geraldine MacKenzie compared herself and her husband favourably with earlier missionaries who objected to arranged marriages. ${ }^{24}$

With the proviso made at Aurukun in the late twenties that the bridegrooms chosen for mission girls should be single and reasonably young, marriages backed by the agreement of all relations of both bride and groom, lasted happily. Early missionaries, before they had time to realise this, had tried to foster a freer, more romantic order of things, understandable to our European way of feeling. ${ }^{25}$

The MacKenzies realised that attachment to 'right' arranged marriages was so strong that a complete objection to them would only increase community turmoil. A 'freer, more romantic order of things' led to conflict, violence, social upheaval and instability.

Christian marriage, and its association with romantic love, freed Aboriginal men and women from traditional arranged marriages. As a child, Dulcie Costello used to hide when her betrothed, an old man, came to visit. Dulcie was immensely relieved when he died: 'Oooh, terrible! Imagine being happy 'cause someone dies, but I was that scared' ${ }^{26}$ Gordon Pablo explained the system of promising and initiation at Injinoo, which ensured that young men and women were ready for marriage. ${ }^{27}$ But Gordon did not marry his promised wife.

Well, I had promised one but - after that coming Christianity coming now everything changed. Christianity was there now.

And, ah, promised one, like I don't know, I got no feeling for that promised one.

So she married another man, I married another woman. ${ }^{28}$

The introduction of Christianity and a different set of laws could be personally liberating, allowing young men and women to follow their hearts.

New ways seemed to provide new freedoms but entailed a lack of choice as access to the old ways was denied. The new freedoms came with new rules and limitations that were set and policed at the discretion of the missionary, Church and State. An increase in individual freedom was thus connected to a cultural loss and a decrease in observance of tradition. 


\section{Making a song and dance about it}

Just as traditional love was related to the power to 'sing', modern love is strongly articulated in song. During the war Gwen Molony played the accordion for the troops at Iron Range: 'Everyone would sing songs. One fellow asked for "You're the only star in my blue heaven", he was a long way from home. I felt sorry for him, he was thinking of someone.'29

Flo Kennedy was hula dancing with an American show company based at a military camp. Her group consisted of Thursday Island men who played guitar and sang: 'I had my own boys play for me ... One day nobody turn up, I don't know what happened.' A white man from another band offered to play for her.

I said, 'You don't play guitar?'

He said, 'No, but I play drums' ...

I said 'Alright'. So I do that and he got his band to play and I danced to his drums ... I was pleased with myself, to find out that I can dance to a white man's drum. ${ }^{30}$

Singing and dancing are not only romantic, they are also spiritual. Flo's family were from Badu Island although she grew up at Lockhart River Mission and Thursday Island. Flo learnt to dance from her Polynesian grandfather.

It's lovely, hula dancing done properly is really nice, with meaning $\mathrm{y}^{\prime}$ know, tell stories ... And it speaks lovely words, $\mathrm{y}^{\prime}$ know the action speaks lovely words.

And it's got to come from inside to make it really meaningful, $y^{\prime}$ know.

I guess anything has to come from inside, otherwise it means nothing. ${ }^{31}$

Aboriginal and Islander people came from a tradition of spiritual observance through song. John Coleman remembers how the old people used to sing while they worked, ${ }^{32}$ and though the songs changed (Gordon Pablo fears in some cases they are lost altogether ${ }^{33}$ ) the singing continued. Church singing was important for many people; Royce Lee praises a family of singers from Hopevale, $^{34}$ Jean George recalls the fine baritone of her uncle. ${ }^{35}$ Aboriginal people were learning 'popular' songs too. Peter Costello's favourite is a sentimental tune about a man missing his mother. The boys on the trochus boat used to sing 'When it's spring-time in the Rockies' and cry for their girlfriends. ${ }^{36}$ Vivien Gostelow and Geraldine MacKenzie recall the Aboriginal stock workers singing to the cattle through the night. ${ }^{37}$ The drovers sang, soldiers sang, men on boats sang.

The women at Weipa used to wait for their men to come home on the boats. As they arrived the men would be singing songs about the islands and the sea: 'Every little thing they make songs about; the wind and the rain, and brother 
and sister. ${ }^{38}$ The song influences from Thursday Island incorporated Islander traditions, modern popular music and Indigenous sentiment. ${ }^{39}$ While the expressions are diverse, the preoccupations remain the same: the main subject of these songs is love, of place, home, family and beloved. Country music is popular to this day with its concentration on rural subjects and the misfortunes of love. ${ }^{40}$

\section{Relationships and community}

Bowie Gostelow's mother, Rose, had to get permission from the Department of Native Affairs to marry her husband, a white pastoralist, as she was under the Aborigines Protection Act. Rose was raised at Silver Plains Station. Her father was an Irishman named Patrick Fox. Her mother died when she was only a week old, and Bowie is unsure about her ancestry, despite her being considered Aboriginal by the government. There was reluctance to talk about Rose Gostelow's origins. In a book written by Bowie's wife she is described as 'Polynesian', but Bowie recognises the possibility of Aboriginal ancestry. ${ }^{41}$

A preference for marrying within the community is apparent throughout Cape York Peninsula. Many people met their spouses through family and local connections. Bowie's wife to be, Vivien Bell, was the daughter of an Endeavour River farming family and went to the same Cooktown school as Bowie, but was six years younger. ${ }^{42}$

In her memoir, Vivien Gostelow took a romantic view of her marriage. An episode on the journey to her new home at Violet Vale, when Vivien's horse bolted, exemplifies her image of Bowie: 'My wonderful sun-bronzed bushman, in his moleskins and legging, blue shirt and battered sombrero, rescued me so effortlessly, just as cowboys did in the movies. ${ }^{43}$ It is not surprising then that Vivien and Bowie fell in love through a shared interest in Westerns. Bowie was ill with his tonsils in Cooktown hospital, where 15-year-old Vivien was working: 'When matron was not around, I slipped in to talk to him, found he liked reading Westerns, and took him some books on my afternoon off. That is how our romance began.' 44

The romance in Vivien's story is not only the love of a cowboy, ${ }^{45}$ but the idealisation of pastoral life. Vivien describes a rural idyll of the station with its fruit trees, fresh milk and wholesome self-sufficiency, and of cattle droving with night-fires and singing. A central image in Vivien's pastoral romance was her mother-in-law, the picturesque matriarch of a pioneer family. ${ }^{46}$ The uncertainty around Rose's heredity is interesting in this respect, for the pioneer woman is always contrasted against the 'wild blacks' and Rose Gostelow is no exception. ${ }^{47}$ In Jon Simon's terms: 'Power relations should always be analysed in terms of adversarial struggle and confrontational strategies. ${ }^{48}$ While the construct of racial conflict remains in place, individuals slip through the gaps. 


\section{Illicit love and illegal relationships}

Queensland law was quite clear on the illegality of sexual relations between Aboriginal people under the Aborigines Protection Act and white, coloured or exempt people not under the Act. The enforcement of this segregation was, as Walter Bowen of Hopevale explains, largely directed at keeping Aboriginal and white men and women apart.

Them days see it's a different law altogether. The Australian law, see, if I were to put a hand on a white girl like this, I'm finished. The police just pick me up, put me up, lock me up ... I can't even go and talk to a white girl, as long as they see me that's it. Whether you're a half-caste or full blood don't make any difference. ${ }^{49}$

The legislation prohibiting inter-racial sexual relationships had been framed as protective, with reference to white men cohabiting with black women, which was seen - and it sometimes was - to be exploitative. In practice, Aboriginal women, as the 'victims', were the ones punished. Attempts by Aboriginal people to enforce their own laws in response to white men's transgressions, particularly through individual spearings in the early period of invasion, were met by the armed force of the settlers. Whole communities could be 'punished' because of allegations of illegal relationships between Aboriginal women and white men. ${ }^{50}$ Numerous women were removed from Cape York Peninsula in the first half of the twentieth century, including 'VD suspects', considered as a category of immoral behaviour. ${ }^{51}$ Concerns over the spread of infectious diseases in Aboriginal and non-Aboriginal populations were valid but greatly exaggerated in the interests of moral and social control, accompanied by issues of 'racial purity'.

European resistance to miscegenation was manifest also in the treatment usually removal and institutionalisation - of 'half-caste' children. When Nancy Ross married she already had a child to a white man. Nancy had been taken from her own family, near Alice River, because her biological father was white. White pastoralists, who knew her father, raised her. As a young single mother Nancy was sent to a dormitory at Yarrabah Mission.

I wasn't used to mission, you know, I wanted to get out.

My husband came down ... I told him I wanted to get out, you know.

We wrote a letter to him, to tell him to come down ...

I was happy in a way, I had a lot of girlfriends there you know.

I just wanted to get out of there, so I got married. ${ }^{52}$

Nancy wanted out of the dormitory but she only agreed to marry when her prospective husband promised to adopt her son as his own. ${ }^{53}$ 
Bamboo Friday and Wampoo Keppel married women to stop them from being removed by the police. These were arranged marriages, agreed to by family and following traditional laws: 'Gotta be right man, any close to family won't let her marry. ${ }^{54}$ Ruby Friday would have been sent to a government settlement or mission because her father was white. Ruby was born in 1942 but married at only 14 years of age to stop her from being taken away. Her husband Bamboo Friday was 19 years older. ${ }^{55}$ Wampoo gives a more general reason for removing young unwed women from the bush: 'If any woman [don't] get married send 'em to Palm Island ... They didn't want any young girls walking around bush, outside, white man making trouble with them.' 56

The cohabitation of white men with black women was commonly tolerated throughout the Cape. ${ }^{57}$ Some men enjoyed the freedom from social (and legal) restraints of living in isolation. They were not legally married. Many had more than one de-facto wife. Those men who wanted to marry their chosen companion had to apply to the Department of Native Affairs for permission, which was sometimes, though not always, granted. ${ }^{58}$

The gendered focus of the Act reflects the cultural assumptions of Europeans about the likelihood of white women having relations with black men. A wife's social standing was determined by her husband, and a white woman could not be placed under the Protection Act. For an Aboriginal man to marry a white woman, it was necessary for him to be exempt from the Act. Authorities appeared reluctant to liberate men on the basis of affection formed with a woman. Exemption was more readily granted to 'half-caste' women to marry non-Aboriginal men. ${ }^{59}$

Aboriginal men who did have relationships with white women were subject to violent beatings by white men. Some are even now uncomfortable about how they might be judged. The guilt associated with these relationships is so strong that men fear being criticised. Many accounts of personal relationships and conflict, though spoken about openly, were specified as not to be made public. One man spoke of his 'best friend' as a white woman he was unable to get permission to marry.

Peter Costello experienced beatings motivated by racial discrimination and sexual jealousy; a beating he received from American soldiers left him with a broken jaw and ribs. ${ }^{60}$ An Italian farmer he worked for agreed to Peter marrying his daughter, but he shied away from marrying a white woman: 'I was shy, you know, shy to come near because of racial, heavy racial ... She had it in mind too, but I wasn't ready.' ${ }^{61}$ Claiming poverty, he left.

Marriage is not only about partnership but one's place within a community. Where communities are divided, the bond of marriage challenges that division. 
In some cases spouses are accepted within closed communities but in times of conflict the couple may just as easily be isolated and excluded.

\section{Censorship and homosexuality}

Opposition can lead to silence. Reluctance to talk about 'inter-racial' relationships on Cape York Peninsula is not as absolute as the lack of comment on same-sex relationships. According to Alberto Manguel the desire to remain unlabelled (and uncensored) is an attempt to protect the limitless possibilities of human expression. Writing about the distinctions of homosexual and heterosexual, Manguel argues: 'our sexual affinities need only declare allegiance and define themselves under duress' ${ }^{6}{ }^{6}$

Perhaps the failure of language is not entirely related to demands for a forced declaration, but indicates a cultural poverty resulting from a 'modern' suppression of the language of non-heterosexual love. In a world 'without' women, the many single men living and working together on Cape York Peninsula suggest different domestic relationships to traditional gender roles, whether they were homosexual or not. ${ }^{63}$ Writing of the masculine environment of colonial Queensland, Clive Moore suggests that male-to-male sex was highly probable but also talks of a culture of mateship as non-sexual romantic friendship. ${ }^{64}$

A Gugu-Yalanji myth, recorded by Ursula McConnel at Bloomfield, tells how Gidja the moon makes a woman out of a younger man. ${ }^{65}$ McConnel's interpretation of the story relates it to the Eve myth of Genesis, comparing a world without women to one defined by their presence. ${ }^{66}$ Nicola Henningham uses this myth as a theme in her discussion of male/female relations. The story also possesses other images, including homosexuality. Gidja, who was often in trouble for having wrongful sex — with close relations for example - is punished for 'making' the young man into a woman. The story has no active feminine principle and the child born from the union dies, showing the marriage to be infertile. I am not claiming this is the 'right' reading but suggesting possibilities inherent in the details of this version of the myth.

Family pressures to marry and produce offspring have plagued homosexual men throughout history. As Jon Simon describes it: 'gay friendship is the proliferation of new forms of relations between people beyond those currently sanctioned, namely marriage and the family' ${ }^{67}$ Waiu Whap, whose family were from Badu, taught and lived at Injinoo and Thursday Island. Waiu's arranged marriage left her in much the same situation as if she had remained single: 'He not really like a man, he a sissy. When I was at Thursday Island, he leave me with my people ... When they want us to live together again, he run away from me ... If I knew I should find another man.' ${ }^{68}$ It was unfortunate for Waiu that her husband felt it necessary (probably due to his own family) to go through with their marriage although he had no desire to be with a woman. 


\section{Reluctance to wed: the love of solitude and independence}

Marriage as an institution of family and state requires permission from parents, from missionaries, from the government. Sometimes it is not the obstacles to marriage but the pressure to wed that ruins romances. On Dulcie Costello's wedding day she had second thoughts: she hid under the bed-covers and the community policeman came several times to fetch her to church. Dulcie didn't feel she had any choice but to marry: 'signed the paper, I don't know what I'm going to do' 69

Reluctance to marry was not an exceptional experience for young men (and women) on the Cape. In his youth George Musgrave preferred solitude and independence. After 'running away' from an Islander girl on Thursday Island he was finally convinced to marry by the Laura police.

Police ask 'George, you like to get married?'

I said 'No way!' ...

He said 'Why not?'

I said 'No, I like to be by myself, can please myself, you can go any way, anywhere you wanted to go' ... 'If you married', I said, 'Soon as you get married, you gonna get a lot of order about, 'do this and do this'. When you by yourself you just roll your swag, pack up and you're gone. ${ }^{70}$

George describes being married as tying one to a place. The Laura police wanted George to stay in the district rather than be sent back to Coen to work on the stations. George's marriage worked not just as an administrative ploy, as through marrying the right woman George had a claim to stay in Laura. His relationship to the land changed from stranger/foreigner to one of belonging: 'Yeah that's why I stop here then ... I was bad up with police. They say "If you get married you'll be tracker ... Then you'll be policeman here". I had mind different way. Police job is really bad. ${ }^{71}$

George was reluctant both at the prospect of marriage and at being coerced into the police force, which he described as dangerous work.

Although Willie Lawrence had doubts, everyone in the community was pleased when he finally wed. They even held a big dance in the Coen hall, usually reserved for white people's functions:

I reckon everybody happy that I got married, they seen me walking around single for the rest of my life ...

Oh dear, made me sorry that time when I got married hey [laugh].

I like single life, you know, good.

Well you can get about hey, you can get lots about. 
You can go anywhere you want to go.

But when you get married, well you never know where you are.

You get a rope around your neck, and you never move ...

They tell you 'Oh you can't go over there!' ${ }^{72}$

Solitude has its own romance: the colourful image of the cowboy, the masculine superiority of the lone bushman, the self-sufficiency of the sailor. The Australian ideal of masculinity, and the images of American westerns value the solitary individualist. Women were not insignificant but they were often absent from the day-to-day working and social lives of men.

Willie and the other men were deeply influenced by Westerns and images of cowboys in books and magazines that reached the remote cattle properties. Movies seen in the towns were also powerful purveyors of modern culture. Most elusive of all in a predominately oral culture was popular song, passed on over campfires and along the road: 'Just give me land, lots of land and the starry skies above - Don't fence me in.'

Being a flash dresser and admired by the women wasn't so bad either. As one man said: 'I was a young man at that time, good rider, and well dressed'. ${ }^{73}$ Men made careful note of their clothing: 'Them white moleskins, them kind we used to wear, and old tweed you know, tight ones you know, look nice too'. ${ }^{74}$

Going one's own way, not being tied down, is such an appealing prospect that even some who married chose this course. Peter Fischer got married because his mother wanted to protect him from jealous husbands and fathers.

Too many women were chasing me. And my mother think world of me, he didn't want 'is son to get in any trouble like ... I had married women all chasing me, I was a beautiful looking young man. My mother growled [at] me then, 'You have to get married'. So she picked me out one there ...

I should have picked one out for meself ... I reckon I'd have been much happier you know. ${ }^{75}$

Peter and his wife raised a large family, seven boys and seven girls, but his wife left him in later life: 'But it was sad, she walked out on me'. Peter Fischer may have been the object of sexual jealousy but he eschews the sentiment: 'I'm not a jealous man, I'm not a woman fighter'. Peter believes it is better to allow people their freedom, even if it means losing them: 'I think maybe better life for her, that she go the way she want to go and I go my way. And that's how we come parted. ${ }^{76}$

Expressions of a 'lost love', and jokes about finding another husband or wife, acknowledge that one's choices are determined by circumstances as much as by 
individual will. But merely raising the possibilities inherent in these regrets is an act of 'rewriting', an act of permanent resistance, intimating not just the possibility of different choices but a different world in which to make them. This questioning of past actions and experiences examines not only individual moral and personal choices but also the definition of those choices by society and community. The modern cultural emphasis on individual freedom has opened up possibilities of multiple partners and non-sanctioned liaisons, but it should be recognised that - as in the romantic epics - these freedoms have also contributed to social and individual turmoil and uncertainty.

\section{End note}

While many of the lovers in these stories form the Cape York Peninsula found happiness, in and out of marriage, none of the stories describe freedom from the presence of family, community, laws and external forces. Perhaps, like Waiu Whap's husband or Idriess' lovers, true escape means running away to 'somewhere else'. Somewhere else is the stuff of songs: 'Over the rainbow'/ 'There's a place for us'. The stories themselves, however, express a freedom to feel and to imagine which is not limited by actual circumstances.

Foucault writes 'The soul is the prison of the body'77 and Blake argues that 'Man has no body distinct from his soul'. ${ }^{78}$ While Blake may accept the soul as prison, in the same sense that 'reason' is the bounded or outer circumference, he would also question this inherent duality. The inside and outside are not merely mutually dependent but more fluid. And, as Simon would have it, 'neither the soul nor the body can be privileged as sites of freedom or the grounds of revolt'. ${ }^{79}$

Songs of love are our insides coming out, as the songs in turn penetrate us. Sometimes our loves are rejected, opposed, disregarded, even despised. We can hide our vulnerability in the language of a mythic story, someone else's words which become our own. Expressions of love in songs and stories can be independent of actions and circumstances. Songs express our experiences both real and imagined. Like love itself they tell the oldest stories newly lived.

The freedom to feel is not the freedom to do, and yet as an expression of our humanity it is essential. If our desires reach their limits then our imaginations take them beyond those limits and make possible an alternative. Our imaginings also show us the ways in which we are constrained. Potential 'transgressive' relationships may not be realised but remain a force for introducing new possibilities.

\section{Acknowledgements}

I wish to thank the people of Cape York Peninsula who made invaluable contributions to my oral history research, without whose time and generosity 
none of my subsequent work would have been possible. In particular, this article has referred to the histories of the following participants, who have given permission for the material to be published:

Walter Bowen, interview tape 29/6/1999.

John Coleman, interview tape 5/7/2000.

Dulcie Costello, interview tape 30/6/1999.

Peter Costello, interview tape 25/6/1999.

Peter Fischer, interview tape 26/6/2000.

Bamboo Friday, interview notes 6/7/1999.

Jean George, interview tape and notes 2/8/2000.

Bowie Gostelow, interview tape 9/11/2000.

Ina Hall, interview tape 12/8/2000.

Flo Kennedy, interview tape 21/9/2000.

Wampoo Keppel, interview tape 7/10/2000.

Willie Lawrence, interview tape 5/10/2000.

Royce Lee, interview tape 19/6/2000.

Gwen Molony, interview tape and notes 16/9/2000.

George Musgrave, interview tape 30/6/2000.

Gordon Pablo, interview tape 23/9/2000.

Nancy Ross, interview tape 12/7/2000 and interview notes 13/7/2000.

Bruce Yunkaporter, interview tape, 28/8/2000.

Waiu Whap, interview notes 4/9/2000.

Gladys Williams, interview notes 19/10/2000.

Silas Wolmby, interview tape 22/8/2000.

\section{References}

\section{Primary sources}

Department of Native Affairs Records, 'Register of Removals 1908-1936', 'Administration Missions — Removals 1941-44' File Series A/64786 \& A/69465, Queensland State Archives, Brisbane.

Security Service Report 2/12/49, 'Survey Cape York Peninsula (within shire of Cook)', A/9108/3 Roll 17/47, National Australian Archives, Canberra.

Thursday Island State High School 1988, 'Torres Strait at War: a recollection of wartime experiences Thursday Island', Thursday Island State High School.

\section{Secondary sources}

Bell, Diane 1998, Ngarrindjeri Wurruwarrin: a world that is, was and will be, Spinifex, Melbourne. 
Blake, William 1790, 'The marriage of heaven and hell', in MH Abrahams et al (ed.), 1986, The Norton Anthology of English Literature, 5th edn, vol 2, WW Norton \& Co., New York and London.

Gostelow, Vivien 1988, Sunshine and shadow, Pinevale Publications, Mareeba.

Henningham, Nicola 2000, 'A different story: gender and the history of white settlement in north Queensland, 1840-1930', PhD thesis, Department of History, University of Melbourne.

Idriess, Ion (1932) 1955, Men of the Jungle, Angus and Robertson, Sydney.

McConnel, Ursula 1933, 'The moon legend from the Bloomfield River, North Queensland', Oceania 3: 9-25.

MacKenzie, Geraldine 1981, Aurukun Diary: 40 years with the Aborigines, The Aldersgate Press, Melbourne.

Manguel, Alberto 1999, Into the Looking-Glass Wood, Bloomsbury, London.

Moore, Clive 1998, 'Colonial manhood and masculinities', in C Moore and K Saunders (eds), 'Australian masculinities: men and their histories', Journal of Australian Studies, special issue volume 56: 35-50.

Parker, David 1994, Ethics, theory and the novel, Cambridge University Press, Cambridge.

Pearson, Noel 1998, 'Guugu Yimidhirr history: Hopevale Lutheran Mission 19001950', in Kociumbas (ed.), Maps, dreams, history: race and representation in Australia, Sydney Studies in History 8, Department of History, Sydney University: 131-236.

Read, Peter 2000, Belonging: Australians, place and Aboriginal ownership, Cambridge University Press, Cambridge.

Rigsby, Bruce 1994, 'Review of literature: Coen and Port Stewart', in B Rigsby and D Hafner, Claim Book; Lakefield National Park Land Claim, Cape York Land Council, Cairns.

Simon, Jon 1995, Foucault and the political, Routledge, London.

Taylor, John 1984, 'Of Acts and Axes: an ethnography of sociocultural change in an Aboriginal community, Cape York Peninsula', Phd thesis, James Cook University, Queensland.

Trezise, Percy 1969, Quinkan Country; Adventures in Search of Aboriginal Cave Paintings in Cape York, AH \& AW Reed, Sydney.

Zeldin, Theodore 1998, An Intimate History of Humanity, Vintage, London.

\section{ENDNOTES}

1 Zeldin 1998: 83.

2 Simon 1995: 93. 
3 Foucault cited by Simon 1995: 92.

4 Simon 1995: 93.

5 Taylor 1984: 268.

6 Taylor 1984: 268.

7 Idriess 1932: 21-30.

8 Idriess 1932: 34.

9 Bell 1998: 155 citing Taplin 1873.

10 Parker 1994: 50.

11 Gwen Molony, interview tape 16/9/2000.

12 Jean George, interview notes 2/8/2000.

13 Jean George, interview notes 2/8/2000.

14 Jean George, interview notes 2/8/2000.

15 Bruce Yunkaporter, interview tape, 28/8/2000.

16 Such a story is told by Bowie Gostelow, interview tape 9/11/2000.

17 Taylor 1984: 271-272.

18 Gladys Williams, interview notes 19/10/2000.

19 Gladys Williams, interview notes 19/10/2000.

20 Gladys Williams, interview notes 19/10/2000.

21 For example see Taylor 1984: 520.

22 Ina Hall, interview tape 12/8/2000. See also Pearson 1998: 171.

23 Ina Hall, interview tape 12/8/2000.

24 MacKenzie 1981: 190.

25 MacKenzie 1981: 49.

26 Dulcie Costello, personal communication, June 1999.

27 Gordon Pablo, interview tape 23/9/2000.

28 Gordon Pablo, interview tape 23/9/2000.

29 Gwen Molony, interview notes 16/9/2000.

30 Flo Kennedy, interview tape 21/9/2000.

31 Flo Kennedy, interview tape 21/9/2000.

32 John Coleman, interview tape 5/7/2000.

33 Gordon Pablo, interview tape 23/9/2000.

34 Royce Lee, interview tape 19/6/2000.

35 Jean George, interview tape 2/8/2000.

36 Peter Costello, personal communication, 1999.

37 MacKenzie 1981: 171; Gostelow 1988: 15.

38 Ina Hall, interview tape 12/8/2000.

39 Contemporary examples are Seaman Dan and the Mills Sisters.

40 See Read 2000: 115-120.

41 Bowie Gostelow, interview tape 9/11/2000.

42 Gostelow 1998: 3-8.

43 Gostelow 1998: 2.

44 Gostelow 1998: 10.

45 Gostelow 1998: 46-7, 65, 168.

46 Gostelow 1998: 15-17.

47 Gostelow 1998: 29.

48 Simon 1995: 84.

49 Walter Bowen, interview tape 29/6/1999.

50 See Rigsby 1994.

51 Department of Native Affairs, 'Register of Removals 1908-1936', Queensland State Archives, Brisbane.

52 Nancy Ross, interview tape 12/7/2000. 
53 Nancy Ross interview notes 13/7/2000.

54 Wampoo Keppel, interview tape 7/10/2000.

55 Bamboo Friday, interview notes 6/7/1999, also Royce Lee, interview tape 19/6/2000.

56 Wampoo Keppel, interview tape 7/10/2000.

57 Security Service, Report 2/12/49, 'Survey Cape York Peninsula (within shire of Cook)', A/9108/3 Roll 17/47, National Australian Archives, Canberra.

58 See Henningham 2000.

59 Such as Rose Gostelow, Therese Heinemann and Tommy Nakata's wife.

60 Peter Costello, interview tape 25/6/2000.

61 Peter Costello, interview tape 25/6/2000.

62 Manguel 1999: 39.

63 For a discussion of the colonial masculine environment and its legacy, see Moore $1998: 39$.

64 Moore 1998: 46.

65 McConnel 1933 details the many complex parts of the story relating to women and community. For a men's version of the story, see Trezise 1969: 92-93.

66 See Henningham 2000: 39-40.

67 Simon 1995: 97

68 Waiu Whap, interview notes 4/9/2000.

69 Dulcie Costello, interview tape 30/6/1999.

70 George Musgrave, interview tape 30/6/2000.

71 George Musgrave, interview tape 30/6/2000.

72 Willie Lawrence, interview tape 5/10/2000.

73 Silas Wolmby, interview tape 22/8/2000.

74 Peter Costello, interview tape 25/6/1999.

75 Peter Fischer, interview tape 26/6/2000.

76 Peter Fischer, interview tape 26/6/2000.

77 Foucault cited in Simon 1995: 84.

78 Blake 1790: 61.

79 Simon 1995: 84 